\title{
The Use of Lafaz Amar on Ijtihad Madhhab towards the Effect of the Salat Law (Study of Ushul Fiqh)
}

\author{
Munawir Sajali \\ Universitas Islam Negeri Sumatera Utara, Indonesia \\ Email: mailto:msajali310@gmail.com
}

\begin{abstract}
:
Lafaz amar is a study of ushul figh that has been explained by the scholars in their books, and lafaz amar also has various forms and types in the Qur'an and hadith, so that it will have different understandings among scholars when understanding these words of amar, however After conducting the research, based on the description and analysis carried out as explained regarding the use of lafaz amar in the Imam Madhhab's ijtihad and its effect on prayer, several conclusions can be drawn as follows: prayer there are 5 forms of lafaz amar used, namely the form offi'il amar mufrad, fi' il amar jama, 'fi'il mudhari with lam amar, using fi'il madhi and using the word El Whereas users of lafaz amar in the 4 books of the 4 Madhhab soffigh scholars, from this research there are also 5 forms of lafaz amar in general, but each Madhhab has differences in the form of lafaz amar which is used as arguments, such as the hanafi Madhhab in his book Hâsyiah Ibn 'Âbidîn has 4 forms of amar lafaz, namely fi' il amar mufrad, fi'il amar jama', lafaz amar fi' il madhi with lafaz أُمِزتُ, كُتِبَ and lafaz amar using lafaz on the Madhhab Mal Fiiki in his book Al-Kâfi Fî Figh Ahli Al-MadînahAl-Mâlikî, there is 1 form of lafaz amar, namely in the form of fi' il amar in jama', then the shafi'i Madhhab in AlUm has 5 forms of use of lafaz amar, including fi'il amar mufrad, fi'il amar jama', fi'il mudhari' with lam amar, and lafaz amar using the lafaz Madhhab in the book called Al-Mughnî there are 5 forms of use of lafaz amar in the book, including: fi' il amar mufrad, fi' il amar jama', fi' il madhi with lafaz 'إفتَرَضَ, and lafaz amar using lafaz عَلَّ.
\end{abstract}

Keywords:

lafaz amar; ushul figh; madhhab; Qur'an; hadith

\section{Introduction}

Islam is the last divine religion that was sent down by Allah SWT to humans as a perfect religion in teaching so that humans do not stray from the right path, Islam is a religion that has a holy book that is used as a guide for life, namely the Qur'an, and the traditions of the prophet Muhammad SAW. explain some of the meanings of the verses of the Qur'an, which are then used as a second source in issuing laws in Islam, both of which are light for humans who follow them, we already know that Islam has regulated the life of humans as a whole, covering all aspects of life, starting from human relations with the Creator, relationships with fellow humans both from themselves, both parents, spouses, children, siblings, neighbors, friends and other communities. The position and function of the Qur'an other than as a holy book of the Qur'an is as a way of life for those who are pious and as a guide or guidance for humanity (Sinaga, 2020). If the Qur'an brought by the Prophet with their language, why they do not want to understand and ask the meaning, such as a variety of lessons and laws, so that they gain happiness in the world and the Hereafter (2020). When we look at the rules in the Qur'an as above, these rules are only part of it in Islam, namely the rules of having a good faith with fellow humans, besides that there are many other rules such as the obligation to worship Allah SW'T, because our purpose was created as well to worship 


\section{Britain International of Humanities and Social Sciences (BIoHS) Journal \\ ISSN: 2685-3868(Online), 2685-1989(Print) \\ Vol. 3, No. 1, February 2021, Page: 203-216}

Him, this is like His words which reads:

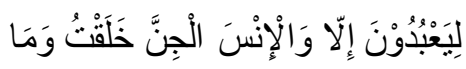

"And I did not create the jinn and mankind except to worship me" (QS. Az-Zariyat: 56)

When looking at the above verse, every Muslim must believe in a strong i'tikad that he is not in this world but for worshiping Allah SWT, so that some people must continue to study religious knowledge so that they always know their purpose for being created on this earth, besides that, it is also necessary to learn the science of ushul fiqh, so that they can ea sily find out the meaning and intentions of God, with the aim of worship being able to be true in accordance with the guidance taught by Islam, so much is the reward of Imam Shafi'I rahimahullah as the first to explain the procedures for understanding the meaning Kalam Allah SWT by explaining several sciences such as Al-Awâmir and An-Nawâhi in the science of ushul fiqh, so that we as the latter can know and can distinguish which commands are obligatory, which are sunnah and which are permissible.

The Qur'an and hadith are two sources of law making in Islam, so to understand both scholars really need various types of knowledge at least four types of knowledge such as ushul fiqh, nahwu Sharaf, An-nâsikh wal-mansûkh, and the narration of hadith knowledge to know the authentic hadith and no, with the four types of knowledge the scholars can understand the contents of the Qur'an and hadith properly and correctly, so that if there is a lafaz either in the form of scientific sentences or fi'liyyahdi sentences in the Qur'an or hadith in the form of orders or prohibitions it can easily be known by the law scholars well.

Imams of the four Madhhab s such as Hanafi Imams, Maliki Imams, Shafi'i Imams and Hambali Imams are great scholars, their words are often used as references by scholars after them, even their books are used as a guide by the scholars after them, no wonder at the end of this era every Muslims in their jurisprudence study become followers of one of the imams of the four Madhhab s, because it is not permissible for someone to leave the four Madhhab s in an opinion if that opinion is contrary to the fourth Imam.

Lafaz amar is closely related to what has been explained by ushul fiqh scholars and nahwu scholars, of course, the most important thing is how the views of ushul fiqh scholars regarding lafaz amar or commands contained in every argument from the Qur'an and traditions related to prayer, because It is very necessary for us to pay attention to the form of each lafaz used in the Qur'an or hadith, especially in this study, the lafaz amar, with the aim that we can see how the scholars understand the lafaz, so that a law can be issued even though the scholars still have differences between one another in a lafaz.

Because of these differences, it is necessary that there be research on the use of lafaz amar in the Imam Madhhab's ijitihad in prayer services, for example the problem of prayer, namely reading the fatihah letter in prayer, one of the four Madhhab says that the letter alFatihah is not obligatory to be read in prayer., in the argument they say is because in the arguments they understand there is using fi'il amar, namely the word فَاقَرَ عُوْْ (read), this piece of word means the command to read what is easy from the Qur'an. four in looking at the meaning of the command in the verse, is it an obligation or just something sunnah or even immutable? Because in the Qur'an and the hadiths there are many verses of the Qur'an in the form of fi'il Amar, but the law is not mandatory and the laws vary. 
There is fi'il amar which has the meaning not obligatory, not sunnah but the meaning is prayer, for example:

$$
\text { الرَّاحِمِيْنَ خَيْرُ وَأَنْتَ مُوَارْحَ اغْفِرْلِيْ رَّبِّ وَقُقْ }
$$

And, (O Muhammad), say, "My Lord, forgive and have mercy, and You are the best of the merciful.” (QS. Al-Mu'minun: 118).

To understand all the uses of the aforementioned lafaz, of course every mujtahid like the imams in the four Madhhab s will have different opinions in responding to every command and statement in the Qur'an and hadith, because each of these imams has the main rules in their Madhhab and is different from the main rules. in other Madhhab s, however, they still agree with the four main references, namely the Qur'an, hadith, ijma and qiyas, so that in this study we will analyze how the use of amar lafaz in the Qur'an and hadiths related to prayer according to the view of the Madhhab four, namely their ushul fiqh scholars, so that the effects can be seen, both positive and negative.

\section{Research Methods}

This study used a qualitative approach that is descriptive analytical and inductive. This study seeked to dig up data to find basic things from phenomena, reality and experiences. This study used documentary studies and analyzed the theories used to explain and conclude the problems raised in this study.

\section{Discussion}

\subsection{Use of Lafaz Amar About Prayers in the Qur'an and Hadith} a. Some of the Lafaz Amar about Prayer in the Qur'an

- Surah Al-Baqarah verses 43:

$$
\text { "And establish prayers." }
$$

- Surat An-Nisa verses 77,102, 103:

Verse 77:

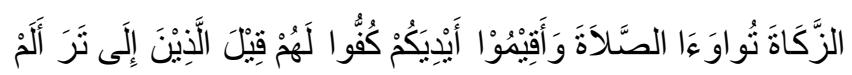

"Don't you pay attention to those people who are told to them" hold your hands from fighting "Establish prayers and pay zakat."

- Surah Al-An'am verse 72:

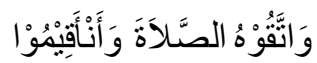

"In order to perform prayers and devote to Him."

- Surah Yunus Verse 86:

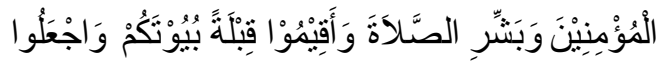


"Make your houses a place of worship, and establish prayers and give good news to those who believe."

- Surah Hud verse 114:

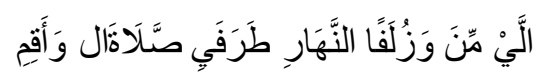

"Establish prayers on both ends of the day (morning and evening) and at the beginning of the night."

\section{B. Lafaz Amar about Prayer in the Hadith}

- The first hadith:

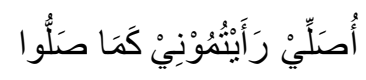

"Pray for you as I pray."

- Second Hadith:

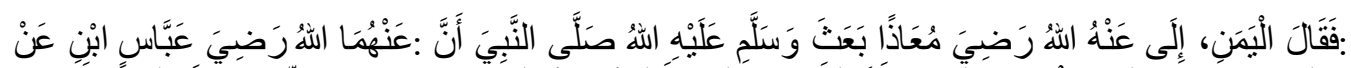

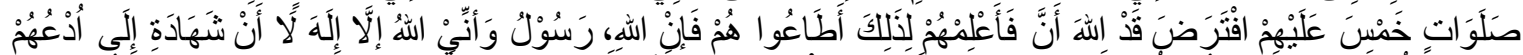

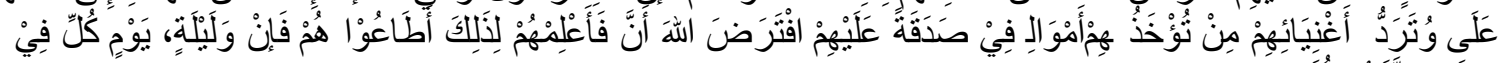

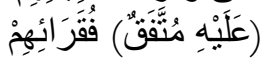

"From ibn 'Abbas that when the Prophet Muhammad SAW sent Mu'az to the land of Yemen, he said: invite them to confess that no God has the right to be worshiped properly except Allah and that I am the Messenger of Allah SWT, if they have obeyed it, then tell them that Allah SW'T obliges them to pray five times a day and night, and if they have obeyed it, then tell them that Allah SWT has obliged them sadaqah (zakat) from their property taken from their rich people and given to their faqir people."

\subsection{The Use of Lafaz Amar on Ijtihad Madhhab towards the Effect of the Salat Law a. The Use of Lafaz Amar on Ijtihad Madhhab}

Book of fiqh from each Madhhab are the Hâsyiah Ibn 'bidîn from the hanafi Madhhab, the Al-Mudawwanah Al-Kubrâ from the Maliki Madhhab, the Al-Um book from the Madhhab Shafi'i, and the Al-Mughnî from the hambali Madhhab.

- The book of Hâsyiah Ibn 'Âbidîn

In the Hâsyiah Ibn 'Âbidîn book, especially with regard to prayer services, there are several types of lafaz amar that have been applied in understanding several laws regarding prayer worship, as a sample there are 14 examples of lafaz amar which are presented so that you can find 4 types of amar lafaz which are applied in the book These include fi'il amar mufrad, fi'il amar jama', lafaz amar fi'il madhi with lafaz أُمِزْتُ كُثَتِ and lafaz amar using lafaz عَلَيٌُْْْ , to see these various examples are listed as below:

- In the form of fi'il amar mufrad verse 78:

On page 10 of volume II, Ibn 'Âbidîn recites the words of Allah SWT, surah Al-Isra'

\footnotetext{
"Perform prayers since the sun slips."
}

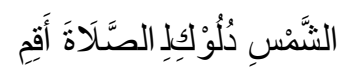


- In the form of fi'il Amar jama'

On page 20 of volume II, Ibn 'Âbidîn recites the hadith of the Prophet from sahih Muslims with hadith number 2937:

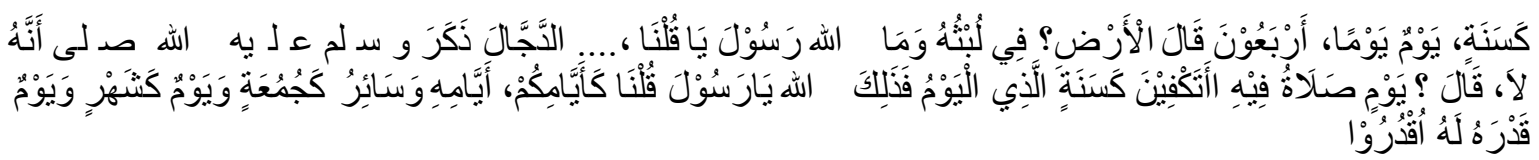

"That Rasulullah SAW told about the Dajjal, the companions asked: O Messenger of Allah, how long was he on Earth? Rasulullah SAW answered for forty days, one day like a year, one day like a month, one day like one Friday (a week) and the rest all days like your days, the companions answered, O Messenger of Allah, for one day like a year Is it enough for us to pray for just one day? Rasulullah SAW said no, set the time according to the level."

- In the form of fi'il madi with lafaz كَنَ

On page 21 of volume II, Ibn 'Âbidîn recites the hadith of the Prophet from Sunan Abi Daud with hadith number 1420:

$$
\text { الْعِبَادِ عَلَى اللهُ كَنَبَهُنَّ صَلَوَاتِ خَمْنُ }
$$

"Five daily prayers are required by Allah SWT to His servants."

- In the form of fi'il amar jama'

On page 25 of volume II, Ibn 'Âbidîn recited the hadith of the Prophet from Sahih Bukhari with the hadith number

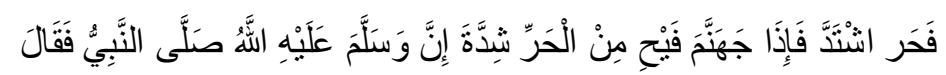

"Rasulullah SAW said: Indeed, the scorching heat comes from the blowing of hell, if the air is very hot then delay prayer (until it subsides)."

- In the form of fi'il amar mufrad

On page 49 of volume II, Ibn 'Âbidîn recites the hadith of the Prophet from Sahih Bukhari with hadith number 597:

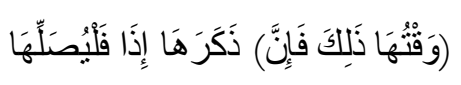

"Then do the prayers again, (because it is the time to replace it)."

- In the form of fi'il amarjama'

On page 134 of volume II, Ibn 'Âbidîn recites from the word of Allah SWT in Surah Al-Hajj verse 77:

\section{"Rukulah you."}

- In the form of fi'il amar jama'

On page 140 of volume II, Ibn 'Âbidîn recites from the word of Allah SWT in Surah Al-Muzammil verse 20:




"Read what is easy for you from the Qur'an."

- In the form of fi'il amar jama'

On page 195 of volume II, Ibn 'Âbidîn recited the hadith of the Prophet from Sahih Bukhari with hadith number 780 :

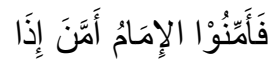

"When the Imam says amen, then say amen."

- In the form of fi'il amarjama'

On page 196 of volume II, Ibn 'Âbidîn recited the hadith of the Prophet narrated by Imam Ahmad with hadith number 7187:

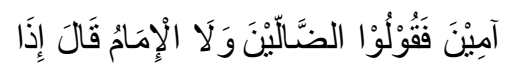

"When the Imam says Waladdhallin then reply with the word amen."

- In the form of fi'il amar jama'

On page 310 of volume II, Ibn 'Âbidîn recites the hadith of the Prophet from Sunan Baihaqi with hadith number 5408:

$$
\text { الْخَلَلَ وَسَدُوْْا الإِمَامَ تَوَسَّطُوْا }
$$

"Make the Imam in the middle and close the empty sidelines."

\section{b. The Book of Al-Kâfi Fî Fiqh Expert Al-Madînah Al-Mâlikî}

After doing research in the book Al-Kâfî Fî Fiqh Expert Al-Madînah Al-Mâlikî it can be found there the use of lafaz amar from the Qur'an and hadiths related to prayer, in this book you can find 3 examples of the use of lafaz amar with 1 the same form. namely fi'il amar in congregation ', to find out the form of lafaz amar in the book are as follows:

- In the form of fi'il amarjama'

On page 40 Ibn 'Abdil Bar recites the verses of the Qur'an in Surah Al-A'raf verse 204:



"When you read the Qur'an, then pay attention and be quiet, I hope you will get mercy." (Surah Al-A'raf: 204)

- In the form of fi'il amarjama'

On page 49 Ibn Abdil Bar recites a Sahih Bukhari hadith No. 908:

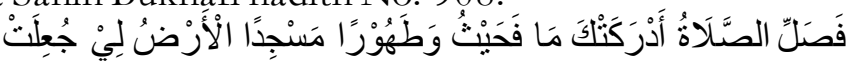
complete."

"The state that you have reached, then follow the prayer, and what you have missed is

- In the form of fi'il amar mufrad

On page 66 Ibn Abdil Bar recites a hadith from Imam Ahmad's musnad with No. hadith 22137: 


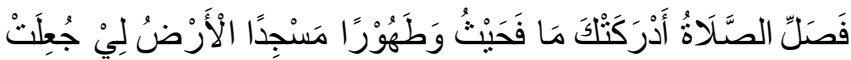

"The earth is made for me as a mosque and holy, wherever prayer meets you, pray."

\section{c. The Book of Al-Um}

In the book of Al-Um, there are many lafaz amar, especially related to prayer, so that there are several forms of using lafaz amar that have been applied to understand several laws regarding prayer worship, as a sample there are 14 examples of lafaz amar that are described, so that 4 can be found. forms of using lafaz amar in the book, including fi'il amar mufrad, fi'il amar jama', fi'il mudhari' with lam amar, and lafaz amar using lafaz كَتَبًَا ، عَلَّى , to see the various examples are listed as follows:

- In the form of amar with the words عَكَتَبًا

On page 149 of volume II, Imam Syafi'i recited verses from the Qur'an in Surah AnNisa verse 103:

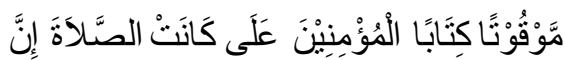

"Truly prayer is a duty which is determined in time for those who believe."

- In the form of fi'il amarjama'

On page 149 of volume II, Imam Syafi'i recited verses from the Qur'an in Surah AlMuzammil verse 20:

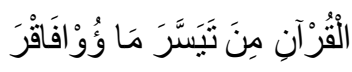

"Read what is easy for you from the Qur'an."

- In the form of fi'il amar mufrad

On pages 149-150 volume II, Imam Syafi'i recites verses from the Qur'an in the letter Al-Isra 'verse 78:

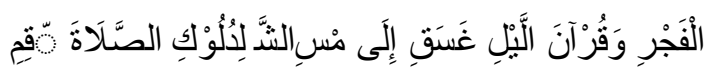

"Do your prayers since the sun slips until it gets dark and until dawn."

- In the form of fi'il amarjama'

On page 175 of volume II, Imam Syafi'i recited the verses of the Qur'an in Surah AlBaqarah verse 238:

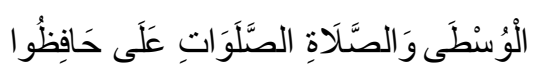

"Maintain all prayers and prayer wustha (asr)."

- In the form of fi'il amarjama'

On page 181 of volume II, Imam Syafi'i recited the verses of the Qur'an in Surah AlJum'ah verse 9:



"If you have been called out to perform your Friday prayers, then hurry to remember Allah and leave the buying and selling." 
- In the form of fi'il amar mufrad

On page 224 of volume II, Imam Syafi'i recited verses of the Qur'an in the chapter AlIsra verse 79 :

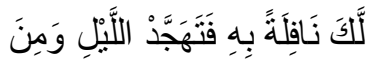

"And on some nights, do the midnight prayer in addition to you."

\section{d. The Book of Al-Mughnî}

In the book of Al-Mughnî, there are many lafaz amar, especially related to prayer, so there are several forms of using lafaz amar that have been applied to understand several laws regarding prayer worship, as a sample there are 8 examples of lafaz amar that are described, so that we can find 5 The forms of using lafaz amar in the book include: fi'il amar mufrad, fi'il

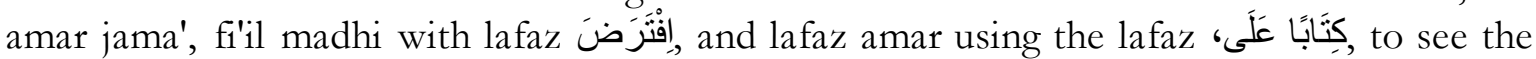
various examples already listed as below:

- In the form of fi'il madhi with lafaz افْتَرَضَ

On page 269 of volume I, Ibn Qudâmah recited a hadith, according to the hadith in Sunan Abî Dâud no hadith 1420:

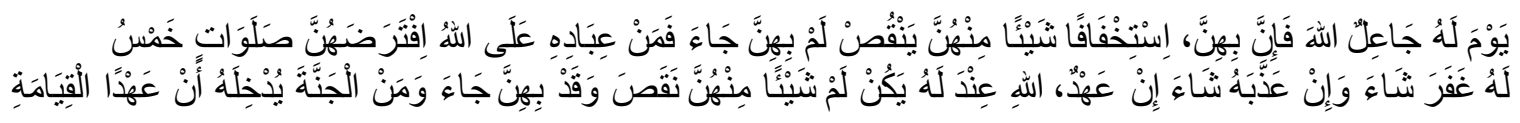

"The five daily prayers which are required by Allah to His servants, whoever comes with his prayer, not the least bit of this prayer is a relief from the prayer service, Allah SWT promises them on the Day of Judgment to enter them into heaven, and whoever. those who come and pray are lacking, then there is no such promise to him, if Allah is willing to give him punishment, if Allah wills he can also forgive him."

- In the form of fi'il amar mufrad

On page 271 of volume I, Ibn Qudâmah recited the words of Allah SWT Surah AlIsra' verse 78:

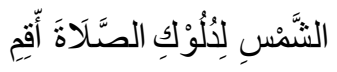

"Perform prayers since the sun slips."

- In the form of fi'il amar jama'

On page 274 of volume I, Ibn Qudâmah recited the words of Allah SWT, surah AlBaqarah verse 238:

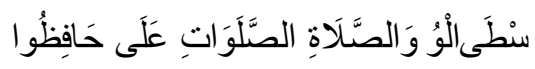

"Maintain all prayers and prayer wustha (asr)."

- In the form of fi'il amar jama'

On page 280 of volume I, Ibn Qudâmah recites a hadith, according to the hadith in Sahih Bukhari no hadith 553:

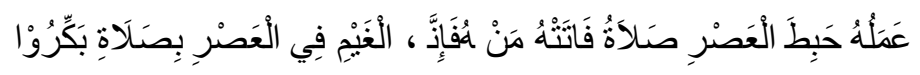

"Give up Asr prayers in winter, because actually whoever is spared from him then his practice will fall." 
- In the form of amarwith the words كs

On page 282 of volume I, Ibn Qudâmah recited the words of Allah SW'T Surah AnNisa verse 103:

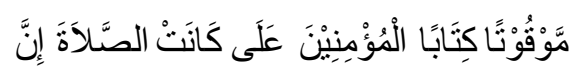

"Truly prayer is a duty which is determined in time for those who believe."

- In the form of fi'il amarjama'

On page 282 of volume I, Ibn Qudâmah recited a hadith, according to the Hadith Sahih Bukhari No. Hadith 536:

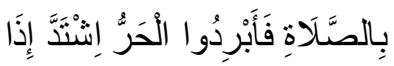

"If the heat is very hot, then slow down the prayer."

\subsection{The Use of Lafaz Amar on Ijtihad Madhhab towards Qur'an and Fatihah for Ma'mum behind the Imam}

The use of lafaz amar in ijtihad imam Madhhab regarding Qur'an, reading fatihah ma'mum behind the imam.

\section{a. Read the Isti’âzah}

The recitation of sti' âzah in prayer is not prohibited, nor is it ordered, but there are differences of opinion among the scholars in responding to every argument they encounter, both from the Qur'an and the hadiths related to reading Qur'an, so that some say sti'âzah reading it is obligatory, there are those who say sunnah absolutely, and there are also those who recommend that only sunnah prayer is not obligatory prayer.

- The arguments about reading Qur'an

Regarding the arguments about reading Qur'an, the argument that can be agreed upon by all Madhhab s of thought is Surah An-Nahl verse 98, namely Allah SWT said:

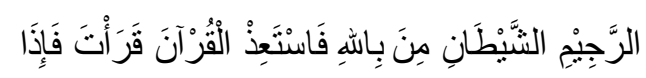
satan."

"If you want to read the Qur'an, then ask protection from Allah from the accursed

- The use of lafaz amar regarding the reading of Qur'an in ijtihad imam Madhhab

Seeing the explanation of the above verse, the argument used about reading Qur'an according to the scholars in the verse uses fi'il amar in the form of mufrad, namely with the

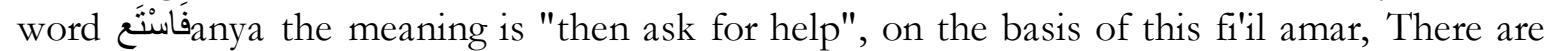
differences of opinion regarding the reading of Qur'an in prayer, so that differences of opinion in it give rise to different laws among them, in addition to the above verses there are also other arguments from the hadith, although the hadith is considered by some scholars to be weak, but still used as evidence, so that there was a difference of opinion among the scholars. To see the opinions of each Madhhab are as follows:

(1) Madhhab Hanafi and hambali

In this matter the hanafi and hambali Madhhab s have the same opinion, namely reading Qur'an is sunnah, and reading it is the first raka'at after takbiratul ihram.

(2) Madhhab Shafi'I

The Madhhab syafi'i also has the opinion that reading Qur'an is sunnah, but not only in the first raka'at, but every raka'at is chanted in the prayer. 
The hanafi, syafi'i and Madhhab hambali say reading the Qur'an sunnah in prayer, they see the evidence from the Qur'an surah An-Nahal verse 98 has the following command sound:

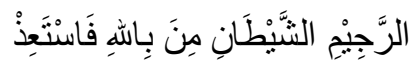

"So ask protection from Allah from the accursed satan."

However, from the arguments of the above verse, still in the view of the hanafi, syafi'i and Madhhab hambali reading Qur'an is not mandatory and the law is sunnah, this is for several reasons as follows:

- The first reason

In it there is fi'il amar, which is the word فَاسنتَع anya which means "then ask for help," but the order cannot immediately become mandatory, but the law can become sunnah, that is what Imam At-Tabarî said, he explained in his interpretation:

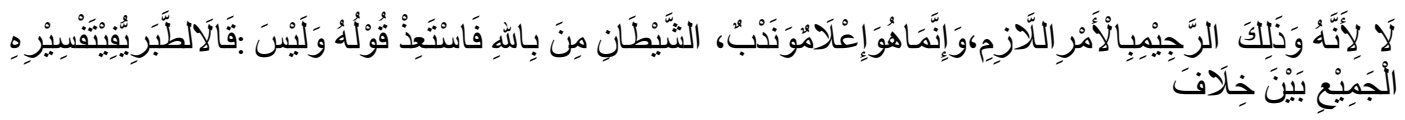

"Said Imam Aț-Tabarî in his interpretation: The Verse of Allah" So ask for protection from Allah from the accursed satan "does not mean that it is obligatory, but means to just tell and the law is sunnah, this is because there is no mistake about it among the scholars."

- The second reason

In the verse the command is not specific, both inside and outside prayer, so when outside prayer, of course the law of reading is not mandatory, of course reading Qur'an will also follow the law of reading the Qur'an outside of prayer, of course the law of reading isti'âzah in prayer is also certainly not obligatory, because it is impossible to distinguish between the law of Qur'an in prayer and outside prayer while the command is general.

\section{b. Readings Fatihah Ma'mum behind the Imam}

1. The Opinion of Madhhab

Regarding the reading of fatihahma'mum behind the imam, there is a difference of opinion among the scholars, so that there are three opinions regarding the reading of the ma'mum when praying in congregation, globally these opinions from each Madhhab are as follows:

- Madhhab Shafi'i says that the ma'mum behind the back does not have to read the prayer reading behind the Imam, either when praying jahar or sir.

- Madhhab Shafi'i is obliged to read the prayer readings behind the Imam when praying jahar or sir.

- Madhhab Maliki and hambali s argue that ma'mum only reads the prayer readings when praying sir, and when ignorant there is no reading.

2. The use of lafaz amar regarding the reading of fatihah ma'mum in ijtihad, behind the Madhhab

- Madhhab Hanafi

- Regarding the reading of the fatihah of the ma'mum behind the imam, Madhhab Hanafi argues with the following hadith: 
(a) The first proposition:

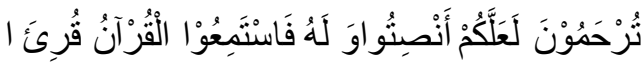

"When the Qur'an is recited, then pay attention and be quiet, I hope you will get mercy." (Surah Al-A'raf: 204). The Madhhab hanafi argues that the above verses of the Qur'an

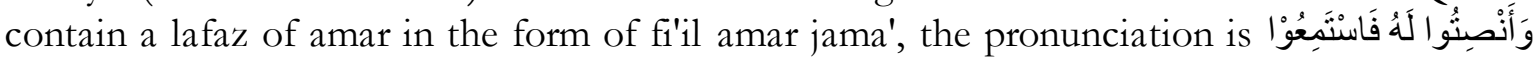
meaning listen and be quiet. Al-Kâsânî in Dubyan explains the verse as follows:

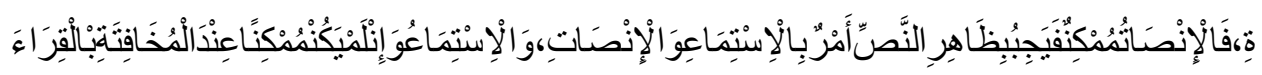

"The command in that verse is to listen and be silent, as for listening, it may not be possible to do it when the reading is slowed down, while the command to be silent can still be done, then the command to be silent is mandatory based on the text of the argument."

(b) The second proposition:

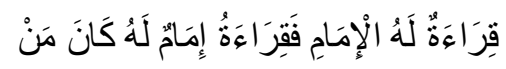

"Whoever has an Imam, the Imam's reading is already his reading."

- Madhhab shafi'i

The reading of fatihah is required for mam'mum behind the Imam, whether it is praying jahar or praying sir, that is the opinion of Madhhab syafi'i, the argument is as follows: (a) The first proposition

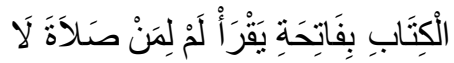

"It is not valid to pray if you do not read the fatihah letter."

(b) The second proposition

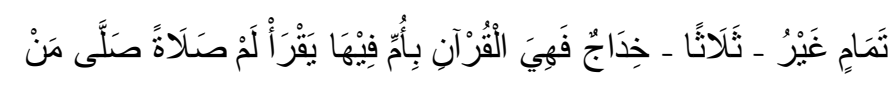

"Whoever prays but does not read the ummul quran in his prayer, then his prayer is khidaj which means imperfect.

- Madhhab Maliki and hambali

In the third view, there is a similarity in opinion between the Maliki Madhhab and hambali, namely the fatihah reading when praying sir, and not reading it when praying jahar, they argue as follows:

(a) The first proposition

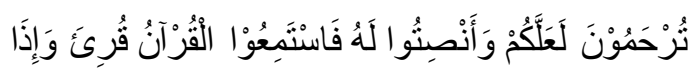

"When you read the jama, then pay attention and be quiet, I hope you will get mercy." (Surah Al-A'raf: 204)

In the above verse used lafaz amar in the form of fi'il amar jama', of course when 
someone reads a verse of the Qur'an both in prayer and outside prayer, he must listen and be silent according to the verse.

(b) The second proposition

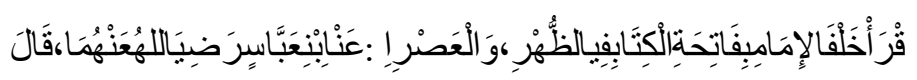

"From ibn Abbas ra he said: read the fatihah letter behind the imam during the midday prayer and the Asr prayer."

It is clear from this history that the lafaz amar used is fi'il amar mufrad, and the command is clear, namely when praying noon and Asr, so that it can be understood that apart from that it is ignorant prayer and it is obligatory to keep quiet and listen to the reading of the Imams.

So in the above narration the lafaz amar used is in the form of fi'il amar jama', and the order is when the imam reads a verse of the Qur'an, then mam'mum must be silent.

- The effect of using lafaz amar on prayer

With some of the arguments from the Qur'an and hadiths regarding the reading of isti'âzah and fatihah letters behind the imam, of course there will be differences of opinion among the scholars, with these differences will certainly have an effect on the law of reading for everyone who reads isti'âzah and fatihah letters in Behind the priest when praying, in $\mathrm{KBBI}$ one of the meanings of effect is an effect, an effect, and something that has an effect of course there will be two effects, namely a positive effect and a negative effect. The negative effect of differences in opinion of the scholars regarding the reading of isti'âzah and surah fatihah ma'mum behind the imam in prayer is that it will have a negative impact on ordinary people, it will only make them confused and there will be divisions among them. The positive effect in general is to add to the scientific treasury for the scholars and preachers in the argument, so that the ulama after them can make their opinion as a reference in religious scholarship.

The positive effects that will be discussed in this study are the positive effects in law such as compulsory, sunnah, makruh and haram, of course with respect to the law of prayer regarding reading isti'âzah and reading ma'mum behind the imam. For more details, let's see the explanation as follows.

\section{Conclusion}

Lafaz amar is a study of ushul fiqh that has been explained by the scholars in their books, and lafaz amar also has various forms and types in the Qur'an and hadith, so that it will have different understandings among scholars when understanding these words of amar, however After conducting the research, based on the descriptions and analyzes carried out as described regarding the use of lafaz amar in the Imam mazhab's ijtihad and its effect on prayer, several conclusions can be drawn as follows:

1. Whereas the use of lafaz amar in the Qur'an and hadiths related to prayer services has 5 forms of lafaz amar used, namely the form of fi'il amar mufrad, fi'il amar jama, 'fi'il mudhari with lam amar, using fi'il madhi and use the word عَلَّ.

2. Whereas users of amar lafaz in 4 books of the 4 Madhhab s of fiqh scholars, from this research there are also 5 forms of lafaz amar in general, but each Madhhab has differences in the form of amar lafaz which is used as argument, such as the hanafi Madhhab in Hâsyiah Ibn ' Âbidîn has 4 forms of lafaz amar, namely fi'il amar mufrad, 
fi'il amar jama', lafaz amar fi'il madhi with lafaz أُمِزْتُ , كُنَبَ and lafaz amar by using lafaz عَلَيُْْْ , so on the Mazfi Fîqh in his book Expert Al-Madīnah Al-Mâlikî, there is 1 form of lafaz amar, namely in the form of fi'il amar in jama', then Madhhab shafi'i in his book AlUm has 5 forms of use of lafaz amar, including fi'il amar mufrad, fi' il amar jama', fi'il mudhari' with lam amar, and lafaz amar using the lafaz Madhhab hambali in the book called Al-Mughnî there are 5 forms of using lafaz amar in the book above but, including: fi'il amar mufrad, fi'il amar jama', fi'il madhi with lafaz إِفْرَضَضَ and lafaz amar using lafaz عَلَّ.

3. Whereas users of lafaz amar against the law of prayer based on the ijtihad of the Imam of the mazhab have an effect on differences of opinion among Madhhab regarding the law of reading isti'âzah and reading ma'mum when behind the Imam when praying, such as reading isti'âzah Madhhab hanafi hambali view sunnah after takbiratul Ihram, the Madhhab Maliki has the sunnah view of every rak'ah, the Madhhab Shafi'i has the makruh view of compulsory prayer, but it is permissible for sunnah prayer. As for the effect of reading ma'mum behind the Imam Hanafi, the view is that there is no ma'mum reading behind the imam in both the jahar and sir prayers, Madhhab Maliki and Hambali view that reading ma'mum is obligatory behind the imam when praying sir, and there is no reading ma'mum behind the imam. When praying ignorant, then the Madhhab Shafi'i of view is obliged to read ma'mum behind the priest when praying, whether it's ignorant prayer or sir prayer.

\section{References}

Ad-Dubyan, Abu Umar Dubyan bin Muhammad, Al-Jâmi’ fî Ahkâm Aṣ-Ṣalâh, Kairo: Dâr AlLu'luah, 14141H/2020, Volume II.

Ahmad, Musnad Imam Ahmad, Riyad: Dâr As-Salâm li An-Nasyri wa At-Tauzî’, 2013.

Al-Asnawî , Jamâluddîn, Nihâyat As-Sûl Fî Syarhi minhâj Al-Ușûl ila 'Ilmi Al-Ușûl, Kairo: Dâr At-Taufiqiyyah li At-Turâs, 2009, Volume I.

Al-Bukhârî ,Muhammad bin Ismâ'̂̂l, Șahị̣̂ Al-Bukhârî, Riyad: Dâr Al-Haḍârah li An-Nasyri wa At-Tauzî', 2015.

Al-Juzairî, 'Abdur Rahmân, Kitâb Al-Fiqhi ‘Alâ Al-Mażâhib Al-Arba'ah, Kairo: Maktabah AtTafíqiyyah, 2008, Volume I.

Al-Hâsyimî, Muhammad 'Alî. Syakhșiyyah Al-Muslim kamâ yasûghuhâ Al-Islâmu fî Al-kitâb wa As-Sunnah, Kairo: Dar Al-Salâm, 2013.

Âlu Sulaimân, Abû 'Ubaidah Masyhûr bin Hasan, At-Tahquîât wa At-Tanqîhât As-Salafiyyât 'Ala Matni Al-Waraqât, Abû Zabî: Dâr Al-Mawaddah, 2005.

Al-Qâdị̂, Abî Ishâq Abdurrahman, Audaḥ al-Bayân fî al-Qirầah khalfa al-Imâm dirâsah fiqhiyyah Hadịșiyyah muqâranah, Țanța: Maktabah Makkah, 2012.

Al-Yâfi'î, Abdul Fattâh bin Șâliḥ, At-Tamażhub dirâsah ta'ṣ̂liyyah muqâranah lil masâil almuta'alliqah bi At-Tamażhub, Yaman, Markâz Al-Khairât, 2018.

An-Naisâbûrî, Abul Ḥasan Muslim, Șahị̣̂ Muslim, Riyad: Dâr Al-Ḥa đ̣̂ârah li An-Nasyri wa AtTauzî', cet. 2, 2015.

An-Nasai, Sunan An-Nasâi, Riyad: Dâr Al-Hậ̣̂arah li An-Nasyri wa At-Tauzî’, 2015.

Aṣ-Ṣâbûnî, Muḥammad 'Alî, Tafsîr Âyât Al-Aḥkâm min Al-Qurân, Kairo: Dâr Aṣ-Ṣâbûnî, 2007, Volume I.

Asy-Syâtibî , Abû Isḥ̂aq bin Ibrâhîm bin Mûsâ bin Muḥammad, Al-Muwâfaqat, Arab Saudi, Dâr Ibn Affân, 1997, Volume IIII.

Aț-Ṭabarî, Tafsîr Aṭ-Ṭabarî Jâmi’ Albayân 'an Ta'wîl âi Alqurân, Kairo: Dâr Hajar, 2011, Volume XIV. 
At-Tirmizî, Ibn Ḍaḥhâaq, Sunan At-Tirmizî, Riyad: Dâr Al-Ḥaḍ̂arah li An-Nasyri wa At-Tauzî', 2015.

Daud, Abu, Sunan Abî Dâud, Riyad: Dâr Al-Ḥaḍ̂âhah li An-Nasyr wa At-Tauzî̀, 2015.

Ismâ'̂̂l, Sya'bân Muhammad, Al-Ijtihâd Al-Jamâ'î Wa Daur Al-Majâmi' Al-Fiqhiy-yah Fî Tațbîqih, Beirut: Dâr Al-Basyâir Al-Islamiyyah, 1998.

Kașîr, Ibn, Tafsîr Al-Qur ân Al-Azîm, Dammam, Dâr Ibn Al-Jauzî, 1431H, Volume, IV.

Majah, Ibn, Sunan Ibn Majah, Riyad: Dâr Al-Ḥaḍârah li An-Nasyri wa At-Tauzî’, cet. 2, 2015.

Muḥammad, 'Alî Jum’ah, Târîkh Ușûl Al-Fiqhi, Kairo: Dâr Al-Muqaț̣am, 2015.

Mûsâ, Aiman bin Alî, Ghâyatul Ma’mûl fi Syarhi al-Bidâyah fi al-Uṣûl, Kairo: Dar Ibn Rajab, Tahun 2012.

Nirwana, A., Hayati, and Ridwan, M. (2020). The Media of Washatiyah Dakwah in Quranic Exegesis Study. Budapest International Research and Critics Institute-Journal (BIRCIJournal) Vol 3 (2): 911-922.

Sinaga, A.I., Ananda, R., and Putri, H.A. (2020). The Role of the Manager of the Qur'an House 'Aisyah Radhiyallahu' Anha in Applying the Living Qur'an Method in Bangun Sari Village, Tanjung Morawa District, Deli SerdangRegency North Sumatra. Budapest International Research and Critics Institute-Journal (BIRCI-Journal) Vol 3, (3): 17181723.

Tim Penyusun, Kamus Bahasa Indonesia (Jakarta: Pusat Bahasa, 2008). 